\title{
PAYUNG HUKUM PELAKSAAN ABORTUS PROVOKATUS PADA KEHAMILAN AKIBAT PERKOSAAN
}

\author{
Rika Susanti \\ Bagian Forensik Fakultas Kedokteran Universitas Andalas \\ E-mail: ifaua@yahoo.com
}

\begin{abstract}
Abstrak
Pada survei yang dilakukan WHO dibeberapa kota besar di Asia pada tahun 1996 di Indonesia ditemukan bahwa pada wanita yang berumur diatas 16 tahun dikota Jakarta dan Surabaya pada 1400 sampel didapatkan 2,7\% pernah mengalami perkosaan. Beberapa korban hamil, dan ingin mengakhiri kehamilan. Hukum di Indonesia (KUHP), menjelaskan bahwa semua usaha dalam rangka menghentikan kehamilan adalah suatu tindak pidana dan tidak dipersoalkan apakah indikasi dari pengguguran kandungan tersebut. Setelah adanya UU Kesehatan RI No 23 tahun 1992, barulah abortus provokatus atas indikasi medis mendapatkan payung hukum. Disini dijelaskan bahwa jika abortus dalam rangka menyelamatkan nyawa ibu atau anak diperbolehkan (indikasi medis). Legitimasi abortus provokatus atas indikasi medis saat ini dianggap tidak mencukupi lagi, sehingga diperlukan pula legalisasi indikasi non medis, seperti pada korban pemerkosaan dan child abuse. Dengan keluarnya UU Kesehatan No.36 tahun 2009, maka sudah melegalkan tindakan aborsi pada kehamilan akibat perkosaan.

Kata kunci: perkosaan, kehamilan, abortus provokatus, payung hukum, KUHP, UU Kesehatan.
\end{abstract}

\begin{abstract}
In the survey conducted by WHO in several major cities in Asia in 1996 in Indonesia found that in women aged over 16 years in the city of Jakarta and Surabaya in 1400 samples were obtained $2.7 \%$ had experienced rape. Some victims become pregnant due to rape action and there is a desire to terminate the pregnancy. The law in Indonesia is regulated in the Penal Code (KUHP), explain determined that all efforts in order to stop the pregnancy is a crime and not questioned whether the indications of such abortions. After the Health Law (Undang-Undang Kesehatan RI) No. 23 of 1992, then provoked abortion on medical indication obtain legal protection. Here was explained that if the abortion in order to save the life of the mother or child is allowed (a medical indication). The legitimacy of provoked abortion on medical indication currently considered no longer sufficient, so that will be required to legalize non-medical indications, such as the victims of rape and child abuse. With the release of the Health Law No.36 of 2009, it had legalized abortion in pregnancies due to rape. Key words : rape, pregnancy, abortus, legal protection, article of the Penal Code, the Law on Health.
\end{abstract}




\section{PENDAHULUAN}

Pengertian aborsi menurut hukum adalah tindakan menghentian kehamilan atau mematikan janin sebelum waktu kelahiran, tanpa melihat usia kandungannya. Juga tidak dipersoalkan, apakah dengan pengguguran kehamilan tersebut lahir bayi hidup atau mati. ${ }^{(1,2)}$

WHO memperkirakan 10-50\% dari kasus aborsi tidak aman berakhir dengan kematian ibu. Angka aborsi tak aman (unsafe abortion) tergolong tinggi, diperkirakan setiap tahun di dunia terjadi sekitar 20 juta aborsi tak aman, 26\% dari jumlah tersebut tergolong legal dan lebih 70.000 aborsi tak aman di negara berkembang berakhir dengan kematian ibu. ${ }^{(3)}$

Seiring dengan perkembangan zaman kasus kejahatan seksual juga semakin meningkat. Salah satu dari sekian kasus kejahatan seksual adalah kasus perkosaan. Pada survei yang dilakukan WHO dibeberapa kota besar di Asia pada tahun 1996 ternyata Indonesia memiliki peringkat tertinggi, yaitu survei pada wanita yang berumur diatas 16 tahun dikota Jakarta dan Surabaya pada 1400 sampel didapatkan $2,7 \%$ pernah mengalami perkosaan, di Beijing pada 2000 sampel $1,6 \%$, di Bombay pada 1200 sampel 1,9\%, dan di Manila pada 1500 sampel sebanyak $0,3 \%$. $^{(4,5)}$

Di Indonesia sendiri belum ada data yang menggambarkan jumlah kasus perkosaan secara keseluruhan. Di PKT (Pusat Krisis Terpadu) Perjan RSCM dapat dilihat variasi jumlah kasus perkosaan dari tahun 2000 sampai 2005. Pada tahun 2000/2001 sebanyak 287 kasus, tahun 2002 sebanyak 192 kasus, tahun 2003 sebanyak 118 kasus, tahun 2004 sebanyak 207 kasus, dan tahun 2005 sebanyak 187 kasus.

Pada kasus perkosaan, beberapa korban mengalami kehamilan akibat tindakan perkosaan tersebut, hal ini tentu akan berdampak buruk terhadap perkembangan jiwa korban, sehingga ada keinginan untuk mengakhiri kehamilan. Selama ini kalau ditinjau dari pandangan hukum di Indonesia, pelaksana aborsi pada kehamilan akibat tindakan perkosaan sebenarnya tidak ada payung hukum yang melindungi, tetapi disatu sisi dari segi etika, tidak mungkin kita membiarkan korban perkosaan yang mengalami trauma psikis hebat akibat kehamilan yang dialaminya. Sehingga akibatnya para korban perkosaan yang hamil tersebut berusaha untuk menggugurkan kandungan dilakukan sendiri atau cara lain yang tidak aman.

Dengan diundangkannya UU Kesehatan No.36 tahun 2009, maka sudah melegalkan tindakan aborsi pada kehamilan akibat perkosaan.

\section{Pandangan pro life dan pro choice} Perbedaaan pandangan inilah yang menyebabkan timbulnya dua aliran yang memperdebatkan masalah aborsi. Menurut K. Bertens, gerakan pro life menekankan hak janin untuk hidup. Bagi mereka mengaborsi janin sama dengan pembunuhan (murder), gerakan pro choice mengedepankan pilihan si perempuan mau melanjutkan kehamilannya atau mengakhirinya dengan aborsi. Pendapat mereka, perempuan mempunyai hak atas tubuhnya sendiri, jadi dia berhak untuk memilih antara dua kemungkinan itu sedangkan orang lain dalam masalah ini tidak dapat ikut campur. ${ }^{(6)}$

\section{Ketentuan mengenai abortus dalam etika kedokteran disebutkan dalam: ${ }^{(7)}$ \\ a. Lafal sumpah dokter Indonesia: Saya akan menghormati setiap hidup insani mulai dari pembuahan.}


b. Pasal 10 KODEKI : Dokter Tindakan pengguguran kandungan wajib mengingat akan menurut KUHP dikategorikan sebagai kewajibannya melindungi tindakan kriminal. Pasal-pasal KUHP hidup tiap insani. yang mengatur hal ini adalah pasal 299 , $341,342,343,346,347,348$ dan $349 .^{(8)}$

Menurut pasal ini segala perbuatan dan tindakan dokter bertujuan memelihara kesehatan pasien, karena itu kehidupan manusia harus dipertahankan dengan segala daya. kesehatan, butir-butir yang berkaitan Namun kadangkala dokter harus dengan abortus buatan legal sebagai mengorbankan salah satu kehidupan berikut: ${ }^{(9)}$

untuk menyelamatkan kehidupan lain yang lebih penting. Dalam hal abortus provokatus medisinalis (abortus terapeutik) kesehatan ibu terkadang menjadi prioritas karena besarnya peranan ibu dalam keluarga.

Aborsi dalam Kitab Undang-Undang
Hukum Pidana (KUHP)
Pengertian kandungan menurut hukum ialah tindakan menghentikan kehamilan atau mematikan janin sebelum waktu kelahiran, tanpa melihat usia kandungannya. Juga tidak dipersoalkan apakah dengan pengguguran kehamilan tersebut lahir bayi hidup atau mati (Yurisprudensi Hoge Raad HR 12 April 1898). Yang dianggap penting adalah bahwa sewaktu pengguguran kehamilan dilakukan, kandungan tersebut masih hidup (HR 1 November 1897, HR 12 April 1898).

Pengertian pengguguran kandungan menurut hukum tentu saja berbeda dengan pengertian abortus menurut ilmu kedokteran, yaitu adanya faktor kesengajaan dan tidak adanya batasan usia kehamilan. $^{(1,2,8)}$

Melihat definisi pengguguran kandungan menurut KUHP, maka semua usaha dalam rangka menghentikan kehamilan adalah suatu tindak pidana. Disini tidak dipersoalkan

apakah indikasi dari pengguguran Tindakan medis dalam bentuk kandungan tersebut. tersebut. tim ahli. tertentu

\footnotetext{
Penjelasan

Ayat (1)
}

\section{Aborsi dalam UU Kesehatan No. 23 Tahun 1992}

Dalam UU No. 23 tahun 1992 tentang Pasal 15

1. Dalam kedaan darurat sebagai upaya untuk menyelamatkan jiwa ibu hamil dan atau janinnya, dapat dilakukan tindakan medis tertentu

2. Tindakan medis tertentu sebagaimana dimaksud dalam ayat (1) hanya dapat dilakukan:

a. Berdasarkan indikasi medis yang mengharuskan diambilnya tindakkan

b. Oleh tenaga kesehatan yang mempunyai keahlian dan kewenangan untuk itu dan dilakukan sesuai dengan tanggung jawab profesi serta berdasarkan pertimbangan

c. Dengan persetujuan ibu hamil yang bersangkutan atau suami atau keluarganya.

d. Pada sarana kesehatan

3. Ketentuan lebih lanjut mengenai tindakan medis tertentu sebagaimana dimaksud dalam ayat (1) dan ayat (2) ditetapkan dengan Peraturan Pemerintah. 
pengguguran kandungan dengan alasan apapun, dilarang karena bertentangan dengan norma hukum, norma agama, norma kesusilaan, dan norma kesopanan. Namun, dalam keadaan darurat sebagai upaya menyelamatkan jiwa ibu dan atau janin yang dikandungnya dapat diambil tindakan medis tertentu.

\section{Ayat (2)}

\section{Butir a}

Indikasi medis adalah suatu kondisi yang benar-benar mengharuskan diambil tindakan medis tertentu, sebab tanpa tindakan medis tertentu itu ibu hamil dan atau janinnya terancam bahaya maut.

\section{Butir b}

Tenaga kesehatan yang dapat melakukan tindakan medis tertentu adalah tenaga yang memiliki keahlian dan kewenangan untuk melakukannya yaitu seorang dokter ahli kebidanan dan penyakit kandungan.

Sebelum melakukan tindakan medis tertentu tenaga kesehatan harus terlebih dahulu meminta pertimbangan tim ahli yang terdiri dari berbagai bidang seperti medis, agama, hukum, dan psikologi.

\section{Butir c}

Hak utama memberikan persetujuan ada pada ibu hamil yang bersangkutan kecuali dalam keadaan tidak sadar atau tidak dapat memberikan persetujuannya, dapat diminta dari suami atau keluarganya.

\section{Butir d}

Sarana kesehatan tertentu adalah sarana kesehatan yang memiliki tenaga dan peralatan yang memadai untuk tindakan tersebut dan telah ditunjuk oleh Pemerintah.

\section{Ayat (3)}

Dalam Peraturan Pemerintah sebagai pelaksanan dari pasal ini dijabarkan antara lain mengenai keadaan darurat dalam menyelamatkan jiwa ibu hamil dan atau janinnya, tenaga kesehatan yang mempunyai keahlian dan kewenangan, bentuk persetujuan, dan sarana.

\section{Pasal 80}

(1) Barang siapa dengan sengaja melakukan tindakan medis tertentu terhadap ibu hamil yang tidak memenuhi ketentuan sebagaimana dimaksud dalam Pasal 15 ayat (1) dan ayat (2), dipidana dengan pidana penjara paling lama 15 (lima belas) tahun dan pidana denda paling banyak Rp 500.000.000,00 (lima ratus juta rupiah).

Sejak dikeluarkannya undang undang kesehatan tahun 1992, barulah abortus provokatus atas indikasi medis mendapatkan payung hukum. Disini dijelaskan bahwa jika abortus dalam rangka menyelamatkan nyawa ibu atau anak diperbolehkan. Palaksanaan abortus juga diatur dalam undang undang ini, bahwa hanya boleh dilakukan oleh dokter ahli kebidanan dan penyakit kandungan.

Diundangkannya UU no 23 tahun 1992 tersebut merupakan titik terang bagi dunia kedokteran oleh karena tindakan abortus provokatus terapeutik yang selama ini mereka lakukan telah memperoleh legitimasi.

Upaya pemecahan masalah biasanya berpeluang untuk menimbulkan masalah baru. Legitimasi abortus provokatus atas indikasi medis saat ini dianggap tidak mencukupi lagi, sehingga diperlukan pula legalisasi indikasi non medis, seperti akibat kegagalan $\mathrm{KB}$, korban pemerkosaan dan child abuse, dan lain lain. 
Aborsi dalam UU Kesehatan No. 36 Tahun $2009^{10}$

\section{Pasal 75}

(1) Setiap orang dilarang melakukan aborsi.

(2) Larangan sebagaimana dimaksud pada ayat (1) dapat dikecualikan berdasarkan:

a. indikasi kedaruratan medis yang dideteksi sejak usia dini kehamilan, baik yang mengancam nyawa ibu dan/atau janin, yang menderita penyakit genetik berat dan/atau cacat bawaan, maupun yang tidak dapat diperbaiki sehingga menyulitkan bayi tersebut hidup di luar kandungan; atau

b. kehamilan akibat perkosaan yang dapat menyebabkan trauma psikologis bagi korban perkosaan.

(3) Tindakan sebagaimana dimaksud pada ayat (2) hanya dapat dilakukan setelah melalui konseling dan/atau penasehatan pra tindakan dan diakhiri dengan konseling pasca

tindakan yang dilakukan oleh konselor yang kompeten dan berwenang.

(4) Ketentuan lebih lanjut mengenai indikasi kedaruratan medis dan perkosaan, sebagaimana dimaksud pada ayat (2) dan ayat (3) diatur dengan

\section{Pasal 76}

Aborsi sebagaimana dimaksud dalam Pasal 75 hanya dapat dilakukan :

a. sebelum kehamilan berumur 6 (enam) minggu dihitung dari hari pertama haid terakhir, kecuali dalam hal kedaruratan medis;

b. oleh tenaga kesehatan yang memiliki keterampilan dan kewenangan yang memiliki sertifikat yang ditetapkan oleh menteri; c. dengan persetujuan ibu hamil yang bersangkutan;

d. dengan izin suami, kecuali korban perkosaan; dan

e. penyedia layanan kesehatan yang memenuhi syarat yang ditetapkan oleh Menteri.

Diundangkannya UU Kesehatan No.36 tahun 2009, memberikan payung hukum bagi pelaksanaan abortus provokatus pada kehamilan akibat perkosaan yang mengalami trauma psikologis. Sehingga pelaksanaan abortus provokatus pada kehamilan akibat perkosaan bisa dilakukan secara aman, akan tetapi UU ini juga memberikan syarat, bahwa abortus hanya boleh dilakukan sebelum kehamilan berumur enam minggu yang dihitung dari hari pertama haid terakhir.

\section{KESIMPULAN}

Abortus provokatus tetap merupakan masalah yang masih kontroversial. Disatu sisi memperbolehkan karena alasan lebih mengutamakan hak ibu sedangkan kelompok lain berpendapat bahwa hak anak untuk hidup yang utama. Legitimasi abortus provokatus di suatu negara sangat tergantung kepada hukum yang berlaku di negara tersebut. Di Indonesia, KUHP menyatakan abortus provokatus adalah suatu tindak pidana. UU Kesehatan No. 23 tahun 1992, abortus provokatus atas indikasi medis diperbolehkan sedangkan UU Kesehatan No. 36 tahun 2009 menambahkan satu peluang lagi yaitu abortus provokatus karena kehamilan akibat perkosaan dengan trauma psikis pada korban diperbolehkan.

\section{KEPUSTAKAAN}

1. Idris, AM, Tjiptomartono, AL. Abortus dan Pembunuhan Anak dalam Penerapan Ilmu 
Kedokteran Forensik Dalam Proses Penyidikan. Sagung Seto, 2008. Hal 168-76.

2. Budiyanto A, Widiatmaka W, Sudiono S, Winardi T, Mun'im A, Hertian, dkk. Ilmu Kedokteran Forensik. Edisi pertama. Jakarta: Bagian Ilmu kedokteran forensik FKUI; 1997.

3. Tutik, Titik Triwulan.Analisis Hukuk Islam Terhadap Prakti Aborsi Bagi Kehamilan Tidak Diharapkan (KTD) Akibat Perkosaan Menurut UndangUndang Nomor 36 Tahun 209 Tentang Kesehatan.

4. World Health Organization. The International crime victim survey in countries intransition: national report. Rome: United Nations Interregional Crime and Justice Research Institute; 1998.
5. Wold Health Organization. Victims of crime in the developing world. Rome: United nations interregional crime and justice research institute; 1998.

6. Bertens, K. Etika. Cetakan Kesepuluh. Gramedia Utama. Jakarta: 2007.

7. Hanafiah, MJ. Reproduksi Manusia Dalam Etika Kedokteran dan Hukum Kesehatan. EGC, 1999. Hal 94102

8. Kitab Undang - Undang Hukum Pidana (KUHP).

9. Undang-Undang No. 23 Tahun 1992 tentang kesehatan.

10. Undang -Undang Kesehatan No. 36 Tahun 2009 tentang kesehatan. 